\title{
The Detection of Partial Albinism at Three Species of Bats (Mammalia: Chiroptera) in European Part of Russia
}

\author{
Dmitriy G. Smirnov' ${ }^{1}$, Vladimir P. Vekhnik ${ }^{2}$, Nailya M. Kurmaeva ${ }^{1}$, Farid Z. Baishev ${ }^{1}$ \\ ${ }^{1}$ Department of Zoology and Ecology, Penza State University, Penza, Russia \\ ${ }^{2}$ Zhiguli Preserve, p/o Bakhilova Polyana, Samara Region, Russia \\ Email: eptesicus@mail.ru, vekhnik@mail.ru
}

Received 27 July 2014; revised 12 September 2014; accepted 27 September 2014

Copyright @ 2014 by authors and Scientific Research Publishing Inc.

This work is licensed under the Creative Commons Attribution International License (CC BY). http://creativecommons.org/licenses/by/4.0/

c) (i) Open Access

\begin{abstract}
The first time for the territory of European Russia describes the cases of catching bats with signs of albinism. This article describes the detection of three species of bats with partial albinism in European part of Russia. There are four animal units of Eptesicus serotinus turcomanus that are stored in Penza State University. They were procured in Astrahan region in 1992 and in 1996. One more animal was found in Volgograd region in 2004. All these animals have white spots of different size and shape on their abdominal part of body. In 2012 it was caught a young female of Pipistrellus nathusii in Samarskaya Luka (Samara region) and in 2013 the scientists found a mature female of Myotis mystacinus. Both animals had a light-colored fur, red eyes and with almost white ears. Moreover, they had pale-pink noses and extremities.
\end{abstract}

\section{Keywords}

Partial Albinism, Eptesicus serotinus, Pipistrellus nathusii, Myotis mystacinus

\section{Introduction}

Albinism refers to congenital absence of pigment of skin, hair, and eye membranes. It is currently believed that albinism is caused by the lack of tyrosinase enzyme, which is necessary for the normal synthesis of melanin-a special substance that affects the dyeing.

Although, albinism is rare, it is noticed in virtually in all vertebrate's taxa [1] [2]. It was first described and studied in 18th century by Carl Linnaeus. The first and the most comprehensive list of white animals was published in the mid-20th century and it continues to grow till today. Nowadays, cases of albinism are known for 
more than 150 species of mammals [1]. Two types of albinism are distinguished: full and partial albinism. By full or true albinism (amelanism) integument color is absolutely white, without a single black spot, and cases of partial albinism appear as akromelanizma, leykizma, roan (silver), piebald (spotted) or seasonal albinism [3] [4].

Bats extremely rare have full or partial albinism [5]. Nowadays, it was registered only in 17 species in Europe [6], whereas worldwide albinism is noticed in 50 species [1] [2] [4] [7]-[14]. It is predominantly animals from Central and Latin America. Each of these species has from one to five individuals who has abnormal coat color that compose about 75 individuals.

That's why we consider that it is necessary to describe some cases of catching bats with signs of albinism in European Russia.

\section{Material and Methods}

The results that were obtained on the basis of long-term studies of bats in Volga region, the Urals, the Northern Caucasus are presented in this article. During winter and summer over 200,000 individuals of 23 species were viewed. All of them lived in these areas. Moreover, the bats that are kept in Penza State University (Penza, PGU), Zoological Institute Russian Academy of Sciences (St. Petersburg), Zoological Museum of the Moscow State University (Moscow), Saratov State University (Saratov), Samara State University (Samara) were studied, too.

\section{Results End Discussion}

Several animals with signs of partial albinism (piebald) were found in Penza State University's collection. This four individuals Eptesicus serotinus turcomanus Eversmann 1840 (Figure 1), were found in some parts of the Lower Volga region. Their morphological characteristics are presented in table (Table 1). Among them were one adult male, which was found on June 13th, 1992 on the Lake Baskunchak in Astrakhan region (coll. PGU No. 468). The territory, where the animal was caught, is a slightly hilly steppe plain (Figure 2). The terrain is extremely challenging for erosion and karst forms, dedicated to the areas of the exit on the surface of the ancient Paleozoic and Mesozoic rocks. Karst landforms are presented in the form of beams, sinkholes, wells, niches and caves. The vegetation consists of grass, sagebrush, sagebrush-grass communities, and wood-in the form of artificial planting. Two adult females were caught on the 20th of June, 1996 in the village Kamenny Yar in Astrakhan region (coll. PGU No. 801 and 804). The animals were housed in maternal colony, which was placed under the wooden paneling of the wall of the Muslim mosque. One young female were caught on the 23rd August in 2004 in the Gornay Proleyka village in Volgograd region (coll. PGU No. 1154). The animal was in the colony of 27 individuals, which was placed between the concrete slab outbuildings for keeping cattle. All of these individuals had white spots of different size and shape, which were located on the ventral side of the body and clearly differed from the general background color of the coat.

Two other cases of partial albinism - leykizm were reported on young females Pipistrellus nathusii (Keyserling, Blasius, 1839) and adult female Myotis mystacinus (Kuhl, 1817). Both individuals were caught on the Samarskaya Luka (Samara region). First caught one on the 8th of July 2012 (Figure 3) on the banks of the Volga river (Figure 4). The animal is fed together with other individuals of its species, flying between the trees at the

Table 1. Morphological indicators of bats with signs of albinism.

\begin{tabular}{|c|c|c|c|c|c|c|c|c|c|}
\hline Species & No. & Sex & $\mathbf{A}$ & $\mathbf{L}$ & C & Au & $\operatorname{Tr}$ & $\mathbf{R}$ & $\mathbf{w}$ \\
\hline E. s. turcomanus & 468 & $0^{\lambda}$ & ad & 67.5 & 54.0 & 21.2 & - & 47.5 & 16.5 \\
\hline E. s. turcomanus & 801 & q & ad & 72.7 & 49.3 & 18.6 & 10.0 & 48.8 & 16.8 \\
\hline E. s. turcomanus & 804 & 우 & ad & 71.5 & 46.1 & 19.4 & 8.9 & 48.1 & 17.9 \\
\hline E. s. turcomanus & 1154 & 우 & s/ad & 74.0 & 48.3 & 18.3 & 10.0 & 48.0 & 17.4 \\
\hline M. mystacinus & & 우 & ad & 40.0 & 34.7 & 14.7 & 6.7 & 34.2 & 6.0 \\
\hline P. nathusii & & 우 & s/ad & 49.9 & 38.4 & 12.1 & 6.7 & 38.4 & 7.9 \\
\hline
\end{tabular}

No.—number in a collection; A—Age; L—body length; C—-tail length; Au—ear length; Tr—tragus; R—forearm length; W—Weight (body mass). 

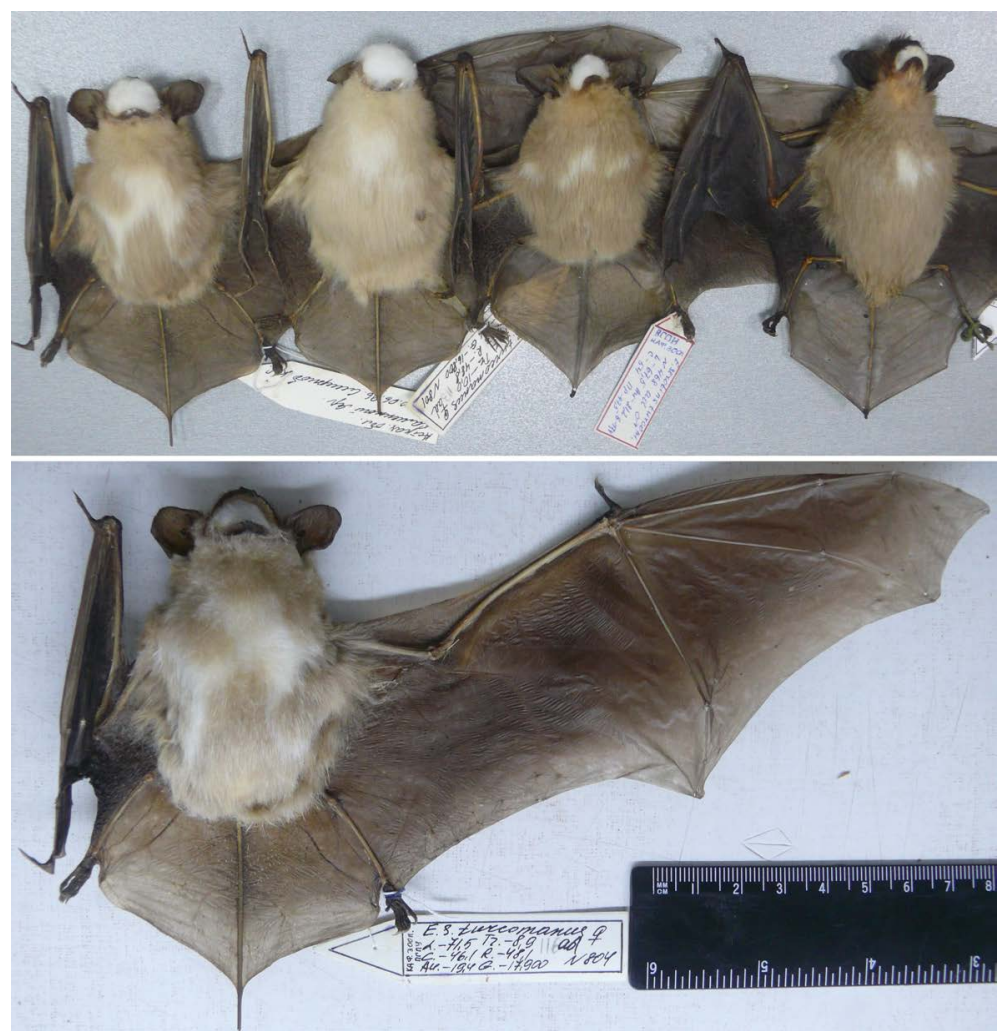

Figure 1. Eptesicus serotinus turcomanus with symptoms of partial albinism.

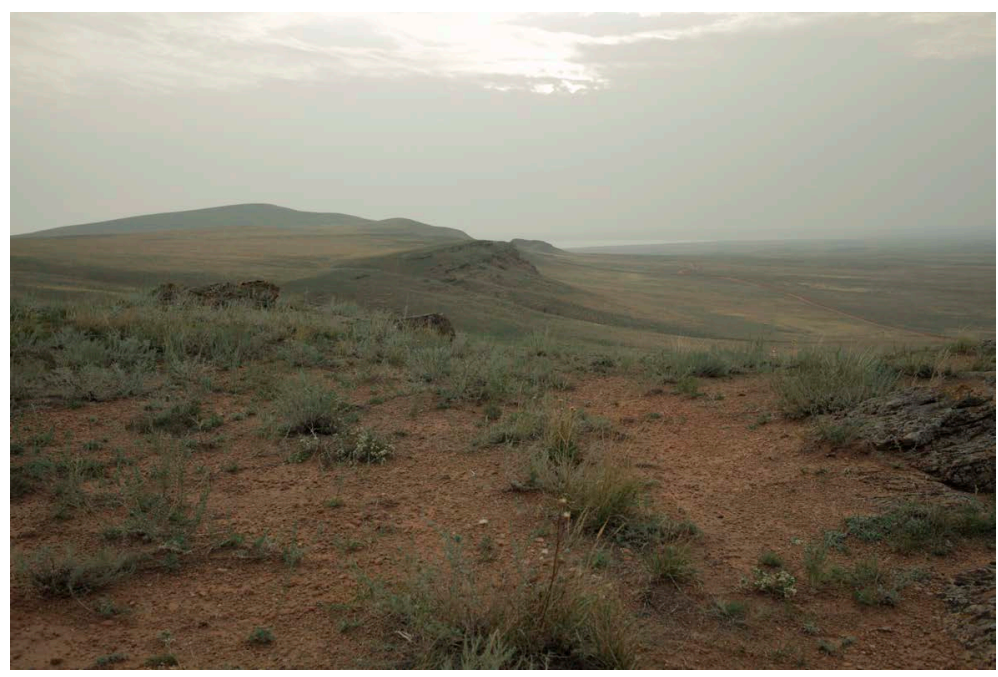

Figure 2. The surroundings of lake Baskunchak Astrakhan region, mountain Bogdo: habitat Eptesicus serotinus turcomanus (photo by D. Smirnov).

level of CZK. The second animal is detected on the 20th of November in 2013 (Figure 5) during hibernation in artificial dungeon on the destruction of $200 \mathrm{~m}$ from the entrance (Figure 6). Animal wintered on the ceiling in a group of four individuals of their own species. The animals had dirty yellow and yellow-fawn color of the coat, red eyes, almost white ears, pale-pink colored limbs and noses. For other morphological indices (forearm length, dentition), they had no differences with other individuals of the same species.

It should be noticed that the detection of the individuals of one breed with signs of albinism is not unique. For example, the capture of the full albino E. serotinus in Moldova [15] is well-known, while in the Netherlands was 


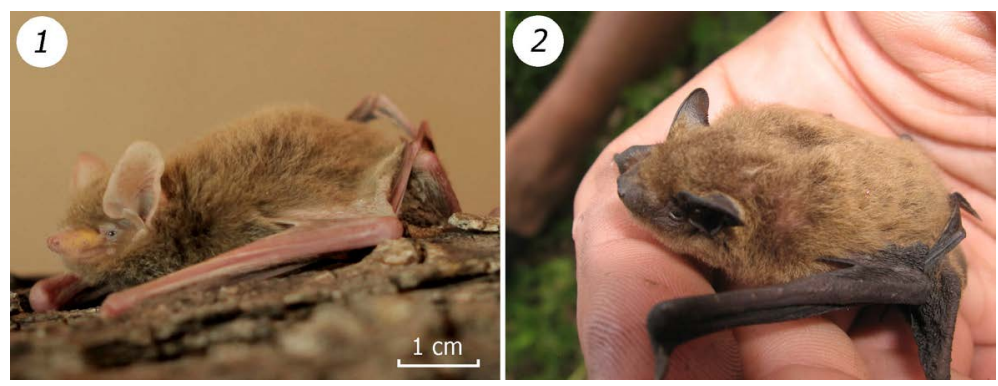

Figure 3. Young individuals of Pipistrellus nathusii with symptoms of partial albinism (1) and with normal coloring of a wool cover (2).

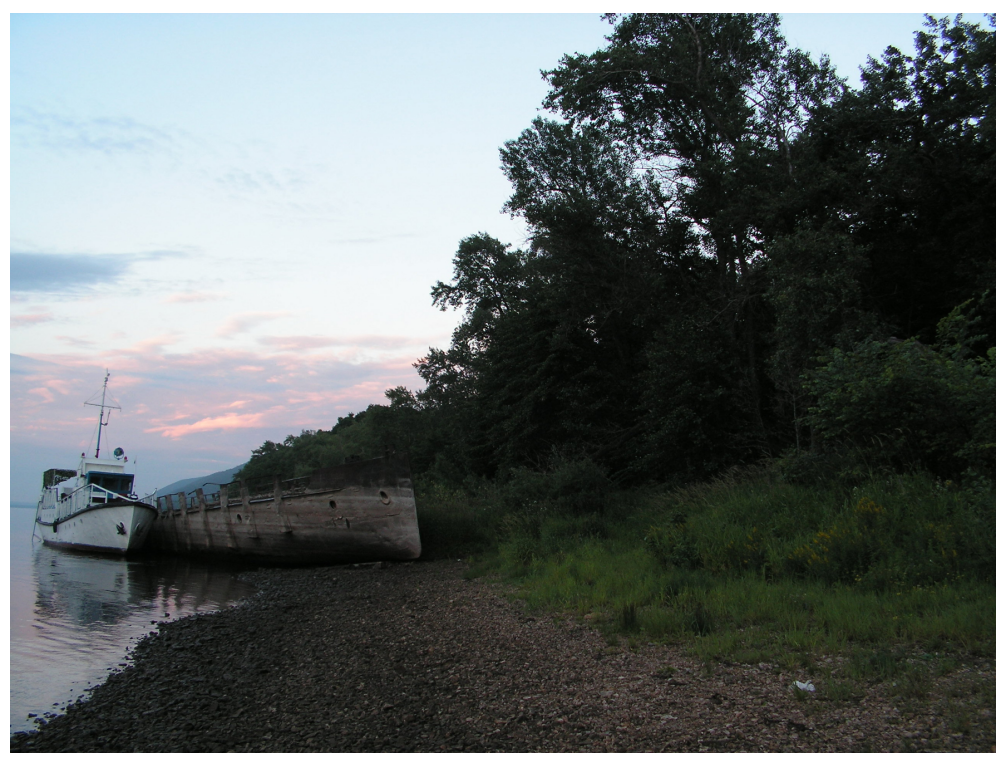

Figure 4. Bank of the Volga river, overgrown with woody vegetation: Habitat Pipistrellus nathusii (photo by D. Smirnov).
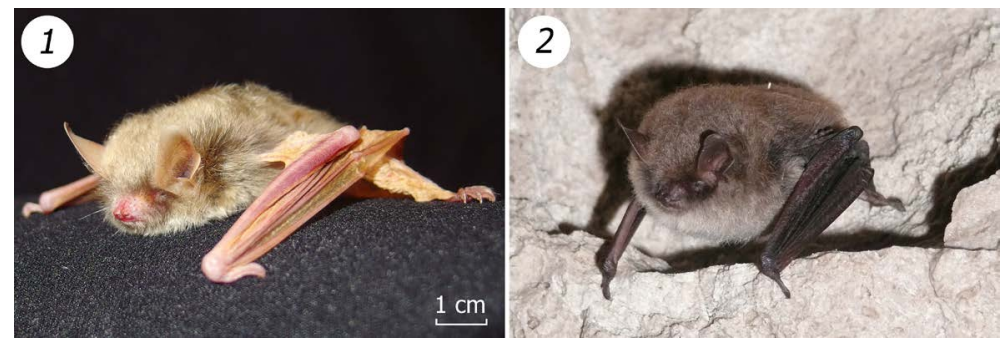

Figure 5. Myotis mystacinus with symptoms of partial albinism (1) and with normal coloring of a wool cover (2).

caught bat with partial albinism (http://www.natuurbericht.nl/?id=3897\&cat=zoogdieren). All this can’t be said about the second breed, because the finding of such animal with an anomaly was made for the first time. However, recently in England with exactly the same features as the $P$. nathusii had, was produced the individual $P$. pygmaeus Leach 1825 (http://www.inmagine.com/imagebrokerrm-081/ptg01125051-photo). Among other relatives of the species $P$. nathusii the full albinism known in Pipistrellus abramus Temminck 1840 [16], P. pygmaeus [7], P. pipistrellus (Schreber, 1774) and P. subflavus (Cuvier, 1832) [2].

M. mystacinus's partial albinism was first registered in the Netherlands [17]. There was caught a male with white colored belly and tips of both wings.

In conclusion, we should notice that detection animals with complete albinism in Russia are virtually unknown. 


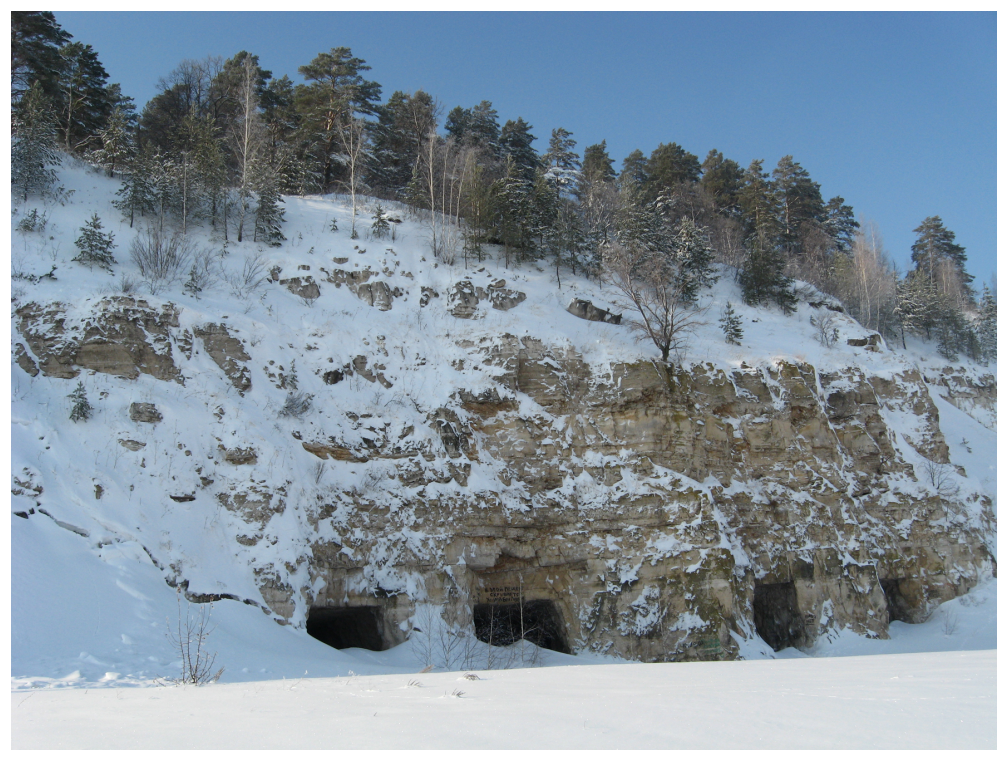

Figure 6. Artificial underground (tunnel) in the Samarskaya Luka: Wintering Myotis mystacinus (photo by D. Smirnov).

The only exception was the only case when the second half of September 2010 in the east part of Russia on Kunashir Island (Southern Kuriles) was caught an almost white individual Myotis macrodactylus (Temminck, 1840) (http://cryptozoology.ru/index.php?name=News\&file=print\&sid=117). According to the staff of the Kuril Reserve the animal should be sent to the Zoological Museum of the Biologosoiled Institute, Eastern Branch of the Russian Academy of Sciences.

\section{References}

[1] McCardle, B.S. (2012) Albinism in Wild Vertebrates. MSC Dissertation, Texas State University, San Marcos, 72.

[2] Uieda, W. (2000) A Review of Complete Albinism in Bats with Five New Cases from Brazil. Acta Chiropterologica, 2 , 97-105.

[3] Herreid II, C.F. and Davis, R.B. (1960) Frequency and Placement of White Fur on Free-Tailed Bats. Journal of Mammalogy, 41, 117-119. http://dx.doi.org/10.2307/1376527

[4] Oliveira, H.F.M. and Aguiar, L.M.S. (2008) A New Case of Complete Albinism in a Bat from Brazil. Chiroptera Neotropical, 14, 421-423.

[5] Feng, L., Jia, T., Shu-Yi, Z. and Qi-Cai, C. (2007) A Partial Albino Bat of Miniopterus magnater Found in Anhui, China. Zoological Research, 28, 443-445.

[6] Gaisler, J. and Pokorný, M. (2002) Second Case of a Partial Albinism in the Noctule Bat (Nyctalus noctula). Nyctalus. (N.F.). Berlin, 8, 179-181.

[7] Quay, W.B. (1970) Integument and Derivatives. In: Wimsatt, W.A., Ed., Biology of Bats, Academic Press, New York, 56.

[8] Brigham, M. and James, A.K. (1993) A True Albino Little Brown Bat, Myotis lucifugus, from Saskatchewan. Blue Jay, 51, 213-214.

[9] Charles-Dominique, P., Brosset, A. and Jouard, S. (2001) Atlas des chauves-souris de Guyane. No. 49. Service du Patrimoine Naturel, Museum d'Histoire Naturelle, Paris, 172.

[10] Barquez, R.M., Carrizo, L.V., Ferro, L.I., Flores, D.A., Mollerach, M.I., Sanchez, M.S. and Garcia Lopez, A.P. (2003) Primer caso de albinismo total para Sturnira erythromos (Tschudi, 1844) (Chiroptera-Phyllostomidae). Chiroptera Neotropical, 9, 166-169.

[11] Sodre, M.M., Uieda, W. and Baldim, M. (2004) First Record of Albinism in the Bat Eumops glaucinus (Molossidae) from Southeastern Brazil. Chiroptera Neotropical, 10, 200-201.

[12] Aul, B. and Marimuthu, G. (2006) Sighting of an Albino Bat in a Colony of Cave-Dwelling Microchiropteran, Hipposideros diadema nicobarensis at the Nicobar Islands. Current Science, 90, 912-914.

[13] Alcalde, J.T. (2009) Myotis alcathoe Helversen \& Heller, 2001 and Pipistrellus pygmaeus (Leach, 1825), New Species 
of Chiroptera in Navarre. Munibe (Ciencias Naturales-Natur Zientziak), 57, 225-236.

[14] Sánchez-Hernández, C., Romero-Almaraz, M.L., Taboada-Salgado, A., Almazan-Catalán, J.A., Schnell, G.D. and Sánchez-Vázguez, L. (2010) Five Albino Bats from Guerrero and Calima, Mexico. Chiroptera Neotropical, 16, 541-545.

[15] Obada, T. and Gas, A. (2003) A Total Albinism in Eptesicus serotinus in Moldova. Studia Chiropterologica, 3-4, 6769.

[16] Hsu, M. (2003) Albinism in the Japanese House Bat, Pipistrellus abramus, and the Formosan Leaf-Nosed Bat, Hipposideros terasensis, in Taiwan. Mammalia: Journal De Morphologie, Biologie, Systematique Des Mammiferes, 67, 451-453.

[17] Van Laar, V. (1994) Partieel Albinisme bij een Baardvleermuis Myotis mystacinus. Lutra, 37, 110-112. http://www.zoogdierwinkel.nl/lutra 
Scientific Research Publishing (SCIRP) is one of the largest Open Access journal publishers. It is currently publishing more than 200 open access, online, peer-reviewed journals covering a wide range of academic disciplines. SCIRP serves the worldwide academic communities and contributes to the progress and application of science with its publication.

Other selected journals from SCIRP are listed as below. Submit your manuscript to us via either submit@scirp.org or Online Submission Portal.
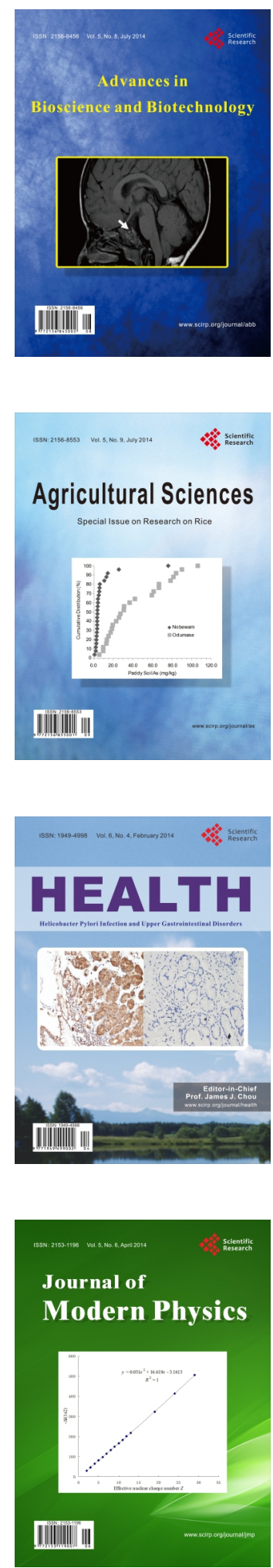
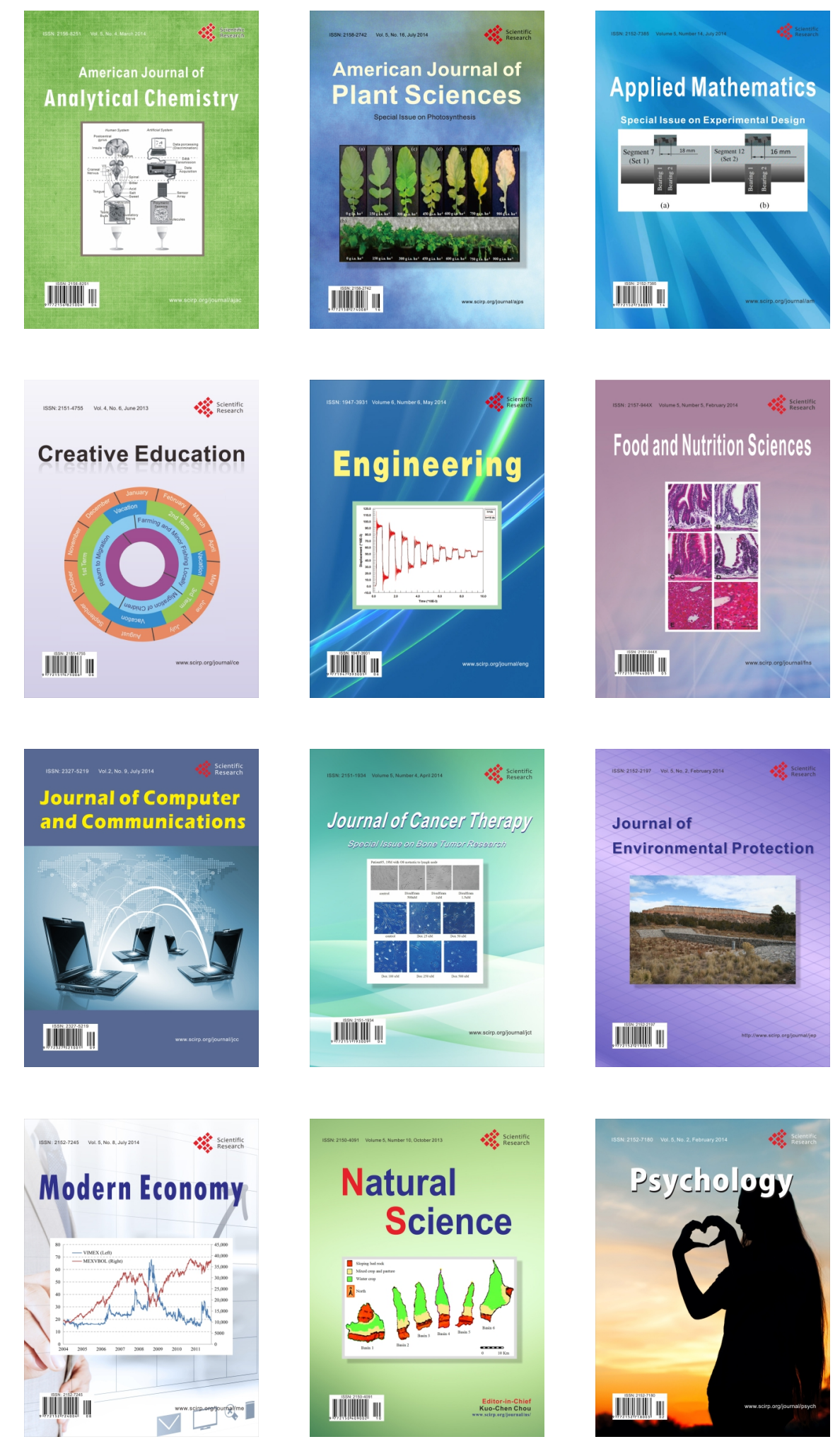